\title{
Adenovirus E1B oncoprotein tethers a transcriptional repression domain to p53
}

\author{
P. Renee Yew, Xuan Liu, and Arnold J. Berk ${ }^{1}$ \\ Department of Microbiology and Molecular Genetics and the Molecular Biology Institute, University of California, Los \\ Angeles, California 90024-1570 USA
}

\begin{abstract}
Many DNA tumor viruses express a protein that inhibits transcriptional activation by the tumor-suppressing transcription factor p53. We report that adenovirus E1B 55K represses p53-mediated activation by a mechanism not described previously. E1B 55K binds p53 without displacing it from its DNA-binding site. A fusion of E1B 55K to the GAL4 DNA-binding domain represses transcription from a variety of promoters with engineered upstream GAL4-binding sites. Mutations within E1B 55K that interfere with its transforming activity and its ability to inhibit p53-mediated trans-activation also interfere with transcriptional repression by the GAL4-55K fusion. These results demonstrate that E1B 55K functions as a direct transcriptional repressor that is targeted to p53-responsive genes by binding to p53.
\end{abstract}

[Key Words: Transcriptional repression; silencing; transformation; repressor]

Received October 19, 1993; revised version accepted November 29, 1993.

p53 protein functions as a tumor suppressor (Levine et al. 1991), and the gene encoding it is the most commonly mutated gene in human tumors /Vogelstein and Kinzler 1992). Recent studies demonstrate that p53 functions as a critical component of a $\mathrm{G}_{1}$ checkpoint induced by DNA damage (Diller et al. 1990; Hartwell 1992; Lane 1992; Lin et al. 1992). Consequently, the absence of p53 function results in genomic instability (Livingstone et al. 1992; Yin et al. 1992). A model for a cell cycle checkpoint pathway postulates that DNA damage activates a protein or set of proteins encoded by AT genes that are defective in patients suffering from ataxia-telangiectasia (AT) (Kastan et al. 1992). The activated AT proteins then induce p53 expression, which in turn induces growth arrest and DNA damage-inducible (GADD) genes, including GADD 45 (Kastan et al. 1992). These events culminate in cell cycle arrest at the $G_{1} / S$ transition where DNA repair may occur (Kastan et al. 1992; Lane 1992, 1993). In the absence of this $G_{1}$ checkpoint, the resulting genomic instability results in DNA rearrangements, gene amplification, and other types of mutations leading to activation of oncogenes, inactivation of tumor suppressor genes, and consequent oncogenic progression. Other studies also show that p53 expression induced by DNA damage results in apoptosis (programmed cell death), perhaps as an alternative to DNA repair (Shaw et al. 1992; Clarke et al. 1993; Lane 1993; Lowe et al. 1993). These results explain why the elimination of p53 activity is an important step in oncogenic progression (Hartwell 1992).

p53 is a sequence-specific DNA-binding transcrip-

${ }^{1}$ Corresponding author. tional activator. Considerable evidence suggests that this biochemical activity is necessary for p53 to function as a tumor suppressor (Vogelstein and Kinzler 1992). The model is that p53 transcriptionally activates genes that prevent entry into $S$ phase and/or genes required for apoptosis. Recent studies show that p53 can bind to the TATA-binding protein (TBP) (Seto et al. 1992; Liu et al. 1993; Truant et al. 1993), a central component of the RNA polymerase Il preinitiation complex, emphasizing the significance of $\mathrm{p} 53$ 's function as a transcriptional activator.

A number of different proteins have been discovered to bind p53 and inhibit its transcriptional activity. Some p53 mutants can oligomerize with wild-type p53, eliminating its DNA-binding ability and, consequently, its transcriptional activity (Bargonetti et al. 1992; Kern et al. 1992). The cellular oncoprotein MDM-2 binds p53 and abrogates its transcriptional activity (Momand et al. 1992). MDM-2 binds to the amino-terminal activation domain of $\mathrm{p} 53$, suggesting that it might function by sterically blocking interactions between the activation domain and general transcription factors (Oliner et al. 1993). However, a recent report indicates that the p53MDM-2 complex cannot bind to a p53-binding site, providing an alternative explanation for MDM-2 repression of p53 activation (Zauberman et al. 1993). In addition, several proteins that are expressed by DNA tumor viruses inhibit p53 activity. The large tumor ( $T$ ) antigen of SV40 forms a complex with p53, inhibiting its DNAbinding activity and, consequently, its transcriptional activity (Bargonetti et al. 1992; Farmer et al. 1992). The human papillomavirus type 16 (HPV-16) E6 protein complexes with p53 and, in cooperation with a cellular pro- 
tein, promotes the polyubiquitination of $\mathrm{p} 53$, resulting in its degradation (Scheffner et al. 1990).

The adenovirus (Ad) early $1 \mathrm{~B}$ (E1B) $55 \mathrm{~K}$ protein also forms a stable complex with p53 in adenovirus-transformed cells (Sarnow et al. 1982a). By studying a panel of E1B $55 \mathrm{~K}$ in-frame insertion mutants, we found that $55 \mathrm{~K}$ inhibited p53-mediated trans-activation in a manner that correlated strictly with the ability of E1B $55 \mathrm{~K}$ to transform cells in cooperation with the early 1A (E1A) protein (Yew and Berk 1992). It is not known how E1B $55 \mathrm{~K}$ negatively regulates p 53 's transcriptional activity, but there are several possible mechanisms. In adenovirus-transformed cells the E1B $55 \mathrm{~K}$ protein has been shown to alter the localization of a large fraction of cellular p53 from its normal site in the nucleus to a discrete cytoplasmic body associated with the nuclear membrane (Zantema et al. 1985b). This sequestration of p53 in a presumably inactive complex has been postulated to be the manner in which E1B 55K may inactivate 553 function. However, two lines of evidence suggest that this is not the principal mechanism by which E1B $55 \mathrm{~K}$ inhibits p53. First, studies with the Ad12 E1B 54K protein, the serotype 12 homolog of Ad2 E1B 55K, showed that the Ad12 54K protein could inhibit p53 trans-activation (Yew and Berk 1992) even though Ad12 54K does not sequester p53 in cytoplasmic bodies (Zantema et al. 1985a). Second, an E1B 55K insertion mutant at amino acid 443 (R443), which binds p53 like wild-type E1B 55K but is defective for both transforming activity and for inhibition of p53 trans-activation (Yew and Berk 1992), retains the ability to sequester $\mathrm{p} 53$ in cytoplasmic bodies (P.R. Yew and A.J. Berk, unpubl.). Sufficient p53 apparently enters the nucleus to permit activation of reporter genes. Consequently, there is no strict correlation between the ability of E1B $55 \mathrm{~K}$ to sequester p 53 in a cytoplasmic body and its ability to inhibit p53-mediated trans-activation.

Another possibility is that E1B $55 \mathrm{~K}$ might interfere with p53's ability to bind to its DNA recognition sequence in a manner analogous to mutant p53, MDM-2, and SV40 T antigen. Because E1B 55K binds to the activation domain of p53 (Kao et al. 1990) it might function by sterically blocking or masking the p53 activation domain, preventing it from interacting with TBP or other possible activation targets. However, mutant R443 binds p53 as well as wild-type E1B 55K yet is defective in transformation and inhibition of p53-mediated transcriptional activation (Yew and Berk 1992). This result suggested to us that E1B $55 \mathrm{~K}$ protein plays a more active role in inhibiting p53-mediated trans-activation than merely sterically masking the p53 activation domain.

To define how E1B 55K inhibits p53-mediated transcriptional activation, we tested whether $\mathrm{p} 53$ can bind to a p53 consensus DNA site while it is simultaneously bound to the E1B $55 \mathrm{~K}$ protein. We also tested whether E1B $55 \mathrm{~K}$ can itself act as a transcriptional repressor when it is brought directly to a promoter by a fused DNAbinding domain. Direct transcriptional repression (Levine and Manley 1989) or transcriptional silencing (Brand et al. 1985; Renkawitz 1990) is analogous to ac- tivation by enhancer-binding proteins. Just as enhancerbinding proteins activate transcription from a variety of promoters by a mechanism largely independent of their position and orientation within a promoter region, direct transcriptional repressors inhibit transcription from a variety of promoters in a largely position- and orientation-independent manner. Our results demonstrate that E1B $55 \mathrm{~K}$ binding to p53 does not interfere with p53's ability to bind to DNA. Consequently, E1B $55 \mathrm{~K}$ can be brought to a promoter through its interaction with p53. We also show that a fusion of E1B $55 \mathrm{~K}$ to the GAL4 DNA-binding domain can function as a potent transcriptional repressor when brought directly to heterologous promoters bearing GAL4-binding sites. This introduces a new function for E1B $55 \mathrm{~K}$ as a direct transcriptional repressor and suggests a unique manner in which $\mathrm{p} 53$ function can be regulated by protein-protein interactions at a p53-responsive promoter.

\section{Results}

E1B $55 \mathrm{~K}$ is brought to a p53-responsive promoter through its interaction with $p 53$

We used two methods to determine whether the E1B 55K protein inhibits $\mathrm{p} 53$ binding to its specific DNA-binding site. First, we tested whether a 55K-p53-DNA complex can be specifically immunoprecipitated using a monoclonal antibody to $55 \mathrm{~K}$. Human p53 was purified from extracts of HeLa cells infected with a p53-expressing recombinant vaccinia virus (Fig. 1D). This p53 was competent to bind ${ }^{35} \mathrm{~S}$-labeled in vitro-translated E1B $55 \mathrm{~K}$ protein in a coimmunoprecipitation assay (data not shown). A labeled DNA fragment containing five p53binding sites from the ribosomal gene cluster (RGC) (Kern et al. 1991; Bargonetti et al. 1992) was incubated with purified p53 and immunoprecipitated with the antip53 monoclonal antibody pAb421. Under these conditions, $\sim 2 \%$ of the probe was immunoprecipitated by the p53 antibody (Fig. 1A, lanes 3,4). A control DNA fragment was not immunoprecipitated (lanes 1,2). When in vitro-translated wild-type E1B $55 \mathrm{~K}$ protein was added to the binding reaction, all of the DNA bound by p53 was immunoprecipitated by the anti-55K monoclonal antibody 2A6 (lane 7). No DNA was immunoprecipitated when using an equivalent concentration (Fig. 1B) of an E1B 55K mutant, H326, defective for p53 binding (Table 1), whereas DNA was efficiently precipitated with an E1B 55K mutant, R443, which binds p53 like wild-type 55K (Fig. 1A, lanes 8,9; Table 1). These results show that E1B $55 \mathrm{~K}$ protein can bind to $\mathrm{p} 53$ while $\mathrm{p} 53$ is bound to DNA at a specific site.

An electrophoretic mobility-shift assay (EMSA) was used in a second assay for the effect of $55 \mathrm{~K}$ on p53 DNAbinding activity. When a DNA fragment with five RGC p53-binding sites was incubated with purified p53 and increasing amounts of a control, unprogrammed reticulocyte lysate, three mobility-shift bands were observed (Fig. 1C, lanes 2-4). All three bands were completely competed away when the reaction was carried out with 
Yew et al.

Figure 1. E1B 55K forms a complex with p53 bound to DNA. (A) DNA immunoprecipitation assay. Purified p53 was incubated with a ${ }^{32}$ P-labeled DNA fragment containing five RGC binding sites (lanes $3-10$ ) or five GAL4 binding sites (lanes $1-2)$. Lanes 1 and 3 contain $2 \%$ of the total input counts used for each of the other samples. The anti-p53 monoclonal antibody pAb421 was used to immunoprecipitate $\mathrm{p} 53$, whereas the anti-55K monoclonal antibody $2 \mathrm{~A} 6$ was used to immunoprecipitate E1B $55 \mathrm{~K}$. H326 is a $55 \mathrm{~K}$ insertion mutant at amino acid 326 that is defective for p53 binding and R443 contains an insertion at amino acid 443 that does not affect p53 binding. $(B)$ Immunoblot of in vitro-translated E1B $55 \mathrm{~K}$ proteins. For each sample, $4 \mu$ l of unlabeled in vitrotranslated E1B $55 \mathrm{~K}$ protein was analyzed by immunoblotting with $2 \mathrm{~A} 6$ anti-55K antibody. (MW) Molecular weight markers. $\mathrm{H} 326$ and R443 are E1B 55K insertion mutants. $(C)$ EMSA. The arrow indicates the mobility of unshifted free probe, and the brackets indicate the shifted p53 species and the $55 \mathrm{~K}-\mathrm{p} 53$ supershifted species. Lanes 2-13 contain $1 \mu \mathrm{l}$ of p53 and are noted $(+)$. The volume of added reticulocyte lysate or lysate programmed with mRNA for the different E1B 55K proteins is indicated in microliters. DNA-protein complexes were analyzed by electrophoresis in a $1.4 \%$ agarose gel. $(D)$ Purified p53. p53 (10 and $50 \mathrm{ng}$ ) purified from VV-p53infected cell extracts was analyzed by SDS-PAGE followed by silver staining.

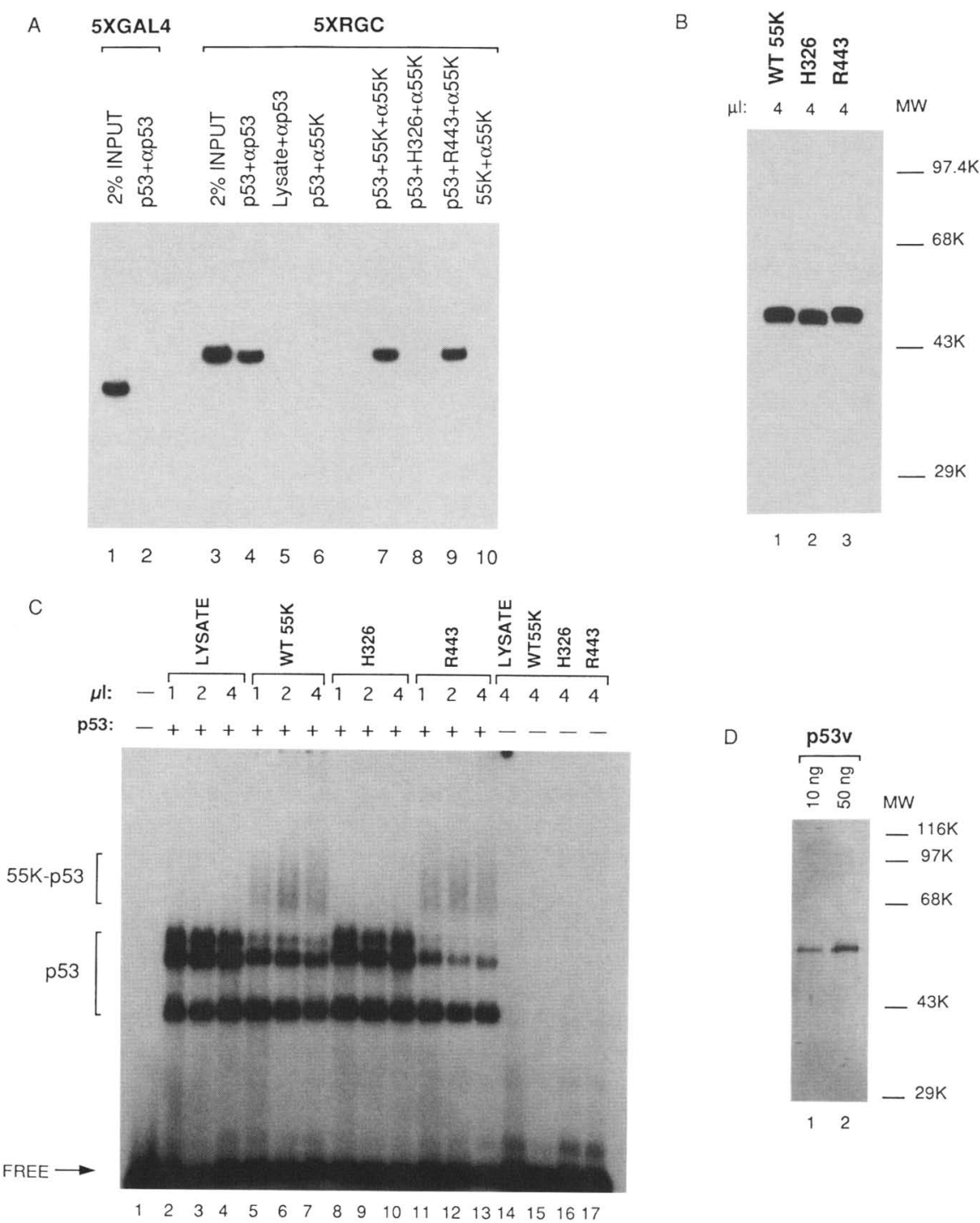

a 100-fold excess of cold RGC DNA fragment but not with a 500-fold excess of cold nonspecific DNA competitor (data not shown). When in vitro-translated E1B 55K protein was added to the reaction, the slowest mobility band decreased dramatically in intensity with a concom- itant appearance of slower mobility complexes (lanes 5-7). The second slowest p53 moblity-shift band was also decreased in intensity, whereas the faster migrating band was unaffected. The supershifted bands were not observed with a mutant E1B 55K protein, H326, which

Table 1. Summary of $E 1 B 55 \mathrm{~K}$ mutant functions

\begin{tabular}{lcccccccccccc}
\hline & H17 & N68 & A143 & H180 & H224 & A262 & R309 & H326 & H354 & S380 & R443 & F484 \\
\hline p53 Binding & + & ++ & +++ & - & +++ & - & - & - & ++ & + & +++ & + \\
Transformation $^{b}$ & ++ & ++ & +++ & - & ++ & - & - & - & +++ & ++ & - & + \\
Inhibition of p53 activation $^{c}$ & N.D. & N.D. & +++ & N.D. & N.D. & - & - & - & +++ & N.D. & - & N.D. \\
GAL4-55K repression & +++ & +++ & +++ & - & +++ & - & - & - & +++ & +++ & - & - \\
\hline
\end{tabular}

$1+++\mid$ Approximately same activity as wild-type E1B $55 \mathrm{~K}_{i}(-)$ approximately same activity as background; (N.D.) not done.

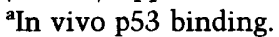

${ }^{\mathrm{b}}$ Transformation of primary baby rat kidney cells.

Inhibition of transcriptional activation by GAL4-p53 and murine p53.

${ }^{\mathrm{d}}$ Not completely defective. 
does not bind $\mathrm{p} 53$, and were again generated by mutant R443, which binds p53 like wild-type E1B 55K (lanes 11-13).

The different mobility-shift bands generated by p 53 may represent binding of p53 to increasing numbers of binding sites or the binding of alternative p53 oligomers. The E1B $55 \mathrm{~K}$ protein appears to preferentially supershift the slowest mobility-shift band, which may indicate that $55 \mathrm{~K}$ binds preferentially to $\mathrm{p} 53$ concentrated at several sites. When the DNA immunoprecipitation assay was used, large amounts of in vitro-translated E1B $55 \mathrm{~K}$ protein could be added, resulting in very efficient immunoprecipitation of p53-DNA complexes. In contrast, the EMSA had strict volume limitations. Consequently, much less E1B 55K protein could be added, which resulted in reduced binding of the p53-DNA complex by ElB $55 \mathrm{~K}$ compared with the immunoprecipitation assay. Also, the intensity of the supershifted complexes did not equal the intensity of the slowest p53 mobility-shift band. This appears to result from the fact that in the presence of E1B 55K or R443 protein, many counts were found in the wells of the gel, indicating that some very large complexes had formed. These results confirm that E1B $55 \mathrm{~K}$ protein can bind to DNA-bound p53 stably enough to supershift a p53-DNA complex. The fact that the supershifted probe in Figure 1C formed a smear rather than a distinct band raises the possibilitiy that $55 \mathrm{~K}$ destabilizes the p53-DNA complex, leading to its dissociation during electrophoresis. However, in the experiment of Figure 1A, the same amount of specific DNA was immunoprecipitated in the 55K-p53-DNA complex as in the p53-DNA complex /cf. lanes 7 and 9 with lane 4). Because the immunoprecipitation procedure involved extensive washing of the immunoprecipates, it is clear that $55 \mathrm{~K}$ binding to $\mathrm{p} 53$ does not greatly decrease the stability of the p53-DNA complex.

Taken together, these results demonstrate that the E1B $55 \mathrm{~K}$ protein does not prevent $\mathrm{p} 53$ from binding to its specific DNA-binding sequence. Moreover, the E1B 55K protein can bind to $\mathrm{p} 53$ that is bound to 553 DNA-binding sites and thus can be brought to a p53-responsive promoter through its specific interaction with p53.

\section{E1B $55 \mathrm{~K}$ acts as a direct transcriptional repressor when directly bound to a promoter region}

In earlier work we found that E1B $55 \mathrm{~K}$ binds to the amino-terminal activation domain of p53 (Kao et al. 1990). This raised the possibility that E1B 55K might inhibit p53 activation simply by sterically blocking the interaction of the p53 activation domain with target molecules in the preinitiation complex. However, a mutant of E1B 55K, R443, was constructed (Yew et al. 1990) that binds to p53 equivalently to wild-type E1B $55 \mathrm{~K}$ yet fails to repress p53-activated transcription (Yew and Berk 1992; Table 1). This result suggested to us that E1B 55K might have an activity in addition to p53 binding required for inhibition of p53-activated transcription. This second activity would be defective in the R443 mutant. We questioned whether this second activity might be similar to that of transcriptional repressors such as the yeast $\alpha 2-\mathrm{Mcml}$ (Johnson and Herskowitz 1985), mammalian thyroid receptor in the absence of hormone (Damm et al. 1989), and Drosophila Krüppel (Licht et al. 1990). These transcriptional repressors inhibit a variety of promoters largely independently of the position at which they bind.

To test whether E1B 55K has the activity of a transcriptional repressor, we constructed a fusion between the DNA-binding domain of GAL4(1-147) and the E1B $55 \mathrm{~K}$ protein and tested whether the fusion protein could repress expression of reporter genes with upstream GAL4-binding sites. Reporter plasmids contained zero, one, or five GAL4-binding sites upstream of the herpes simplex virus thymidine kinase (HSV TK) promoter $(-105$ to +51$)$ controlling expression of chloramphenicol acetyltransferase (CAT) (Fig. 2A). CAT expression was unchanged when the GOTKCAT reporter was cotransfected with increasing amounts of a plasmid expressing GAL4-55K. However, when the GITKCAT or G5TKCAT reporter was cotransfected with the GAL4 $55 \mathrm{~K}$-expressing plasmid, a marked repression in CAT activity was observed, whereas no repression was observed with the GAL4 DNA-binding domain alone (Fig. 2B). CAT activity was reduced to $13 \%$ of the activity observed in the absence of a GAL4 fusion protein for G1TKCAT and $8 \%$ for G5TKCAT. Cotransfection of vectors expressing wild-type or mutant $55 \mathrm{~K}$ proteins that are not GAL4 fusions had no effect on CAT expression from G5TKCAT (Fig. 2C), demonstrating that the 55K protein must be bound to the TK promoter region by the GAL4 DNA-binding domain to repress expression. The effects of other GAL4 fusion proteins were analyzed to test the specificity of repression by GAL4-55K (Fig. 2C). As expected, GAL4-VP16 markedly increased the level of CAT activity observed, whereas a fusion to a transcriptionally defective mutant of the adenovirus E1A activation domain (Martin et al. 1990) had no effect. Significantly, a GAL4 fusion to the homologous Ad12 54K E1B protein also repressed CAT expression from G5TKCAT. GAL4-55K repression was also observed using CV-1, NIH-3T3, and COS cells, indicating that the repression was not cell line specific (data not shown).

These results demonstrate that the E1B 55K protein can function as a potent transcriptional repressor when directly bound to the TK promoter region. This is the first biochemical activity to be attributed to the adenovirus E1B $55 \mathrm{~K}$ protein, aside from specific p53-binding activity. These results indicate that the E1B $55 \mathrm{~K}$ protein does not merely block the transcriptional activity of p53 by masking its activation domain but rather plays an active role in repressing transcription from p53-responsive promoters.

\section{E1B $55 \mathrm{~K}$ can function as a general transcriptional repressor on both weak and strong promoters}

To determine whether the E1B $55 \mathrm{~K}$ protein can function as a general repressor of transcription, we tested the effect of GAL4-55K on expression from the strong SV40 
A REPORTER

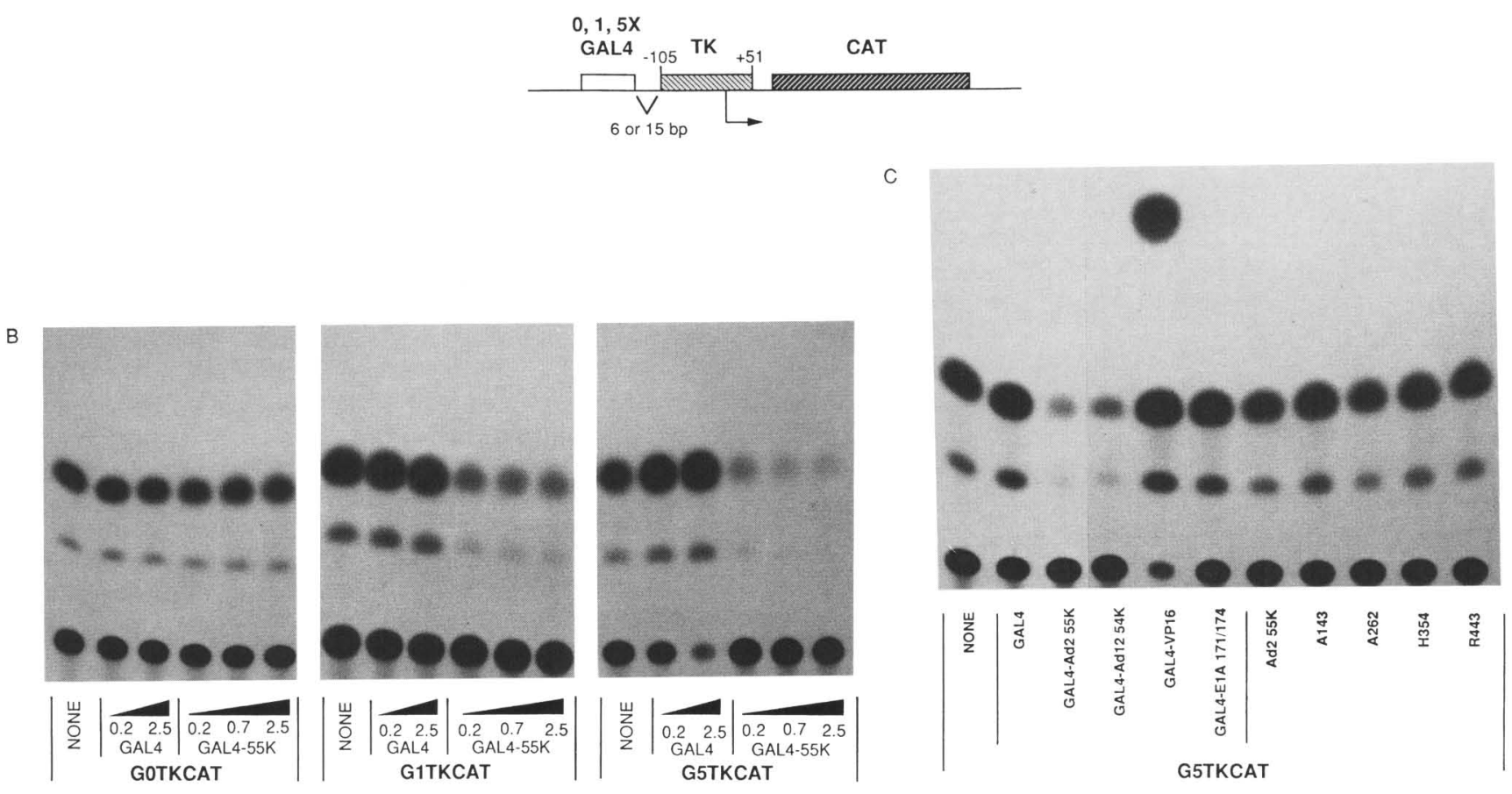

Figure 2. GAL4-55K represses CAT activity from a TK promoter with upstream GAL4-binding sites. (A) TK reporter templates. GOTKCAT contains no GAL4-binding sites, whereas G1TKCAT contains one GAL4-binding site 111 bp from the transcription initiation site. G5TKCAT contains five GAL4-binding sites $120 \mathrm{bp}$ from the transcription initiation site. $(B)$ CAT assay on TK reporters. The reporters were transfected at $7 \mu \mathrm{g}$ per sample. Each reporter was tested with the reporter alone (NONE), with increasing amounts of the GAL4 plasmid expressing the DNA-binding domain of GAL4(1-147) at $0.2 \mu \mathrm{g}$ and $2.5 \mu \mathrm{g}$, and with increasing amounts of the GAL4-55K-expressing plasmid at $0.2,0.7$, and $2.5 \mu \mathrm{g}$. The CAT activities for each sample were quantitated using a Molecular Dynamics PhosphorImager. The values were all normalized to the CAT activity of the reporter alone (NONE), which was set at $100 \%$. These values are representative of at least three experiments for each sample tested. The values are listed in order from left to right for each panel. G0TKCAT: 100, 110, 96, 85, 90, 82. G1TKCAT: 100, 114, 98, 16, 14, 13. G5TKCAT: 100, 200, 243, 24, 12, 8. (C) CAT assay with other GAL4 fusions and E1B $55 \mathrm{~K}$ proteins. GAL4-Ad2 $55 \mathrm{~K}$ expresses a fusion protein between GAL4 and E1B $55 \mathrm{~K}$ of adenovirus serotype 2, and GAL4-Ad12 54K expresses a fusion between GAL4 and E1B 54K of adenovirus serotype 12. GAL4-VP16 expresses GAL4 fused to the activation domain of the HSV transcriptional activator VP16. GAL4-E1A 171/174 expresses GAL4 fused to a mutant of the ElA transcriptional activator that is defective for transcriptional activity (Martin et al. 1990). The plasmids expressing Ad2 E1B 55K wild type and 55K insertion mutants A143, A262, H354, and R443 were all expressed from the strong pcDL-SR $\alpha-296$ expression vector (Yew and Berk 1992). The G5TKCAT reporter was transfected at $6.5 \mu \mathrm{g}$ per sample, along with 2.5 $\mu \mathrm{g}$ of the GAL4 expressing plasmids except GAL4-VP16, which was transfected at $0.1 \mu \mathrm{g}$. The E1B 55K-expressing plasmids were transfected at $1 \mu \mathrm{g}$ per sample. The levels of CAT activity were quantitated and are listed in order from left to right where the activity of the reporter alone (NONE) was set at 100\%. G5TKCAT: 100,173, 14, 17, 435, 187, 80, 136, 62, 98, 91. These values are representative of at least three experiments for each sample tested.

early control region (complete enhancer plus promoter) and the relatively weak (in uninfected cells) adenovirus 2 major late promoter (MLP), both placed downstream of five GAL4-binding sites (Fig. 3A). Both promoters were strongly repressed by GAL4-55K (Fig. 3B,C) but not by a GAL4 fusion to a mutant of $55 \mathrm{~K}$ defective for $\mathrm{p} 53$ repression (Table 1). These results demonstrate that GAL4$55 \mathrm{~K}$ can function as a transcriptional repressor when bound to three different promoters that have no single activator binding element in common. In the case of the strong SV40 promoter, GAL4-55K represses transcription from a distance of $\sim 530$ bp from the transcription initiation site. This ability to repress transcription of multiple promoters from a distance is referred to as di- rect transcriptional repression (Levine and Manley 1989) or transcriptional silencing (Renkawitz 1990).

\section{E1B $55 \mathrm{~K}$ direct repression function maps to three regions of the protein}

An E1B 55K mutant with a 4-residue insertion at amino acid 443 (mutant $R 443$ ) is defective for inhibition of p53mediated activation even though it retains a wild-type ability to bind p53 (Yew and Berk 1992; Table 1) and to bind to a p53-DNA complex (Fig. 1A). We tested whether this defect in p53 repression is the result of a defect in function as a direct repressor by constructing a GAL4 fusion to the R443 mutant and assaying its ability 

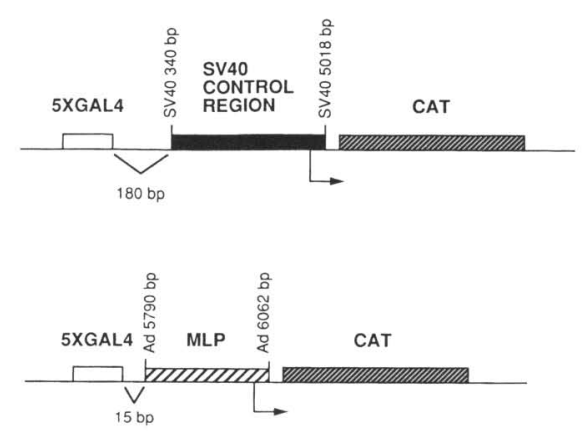

B
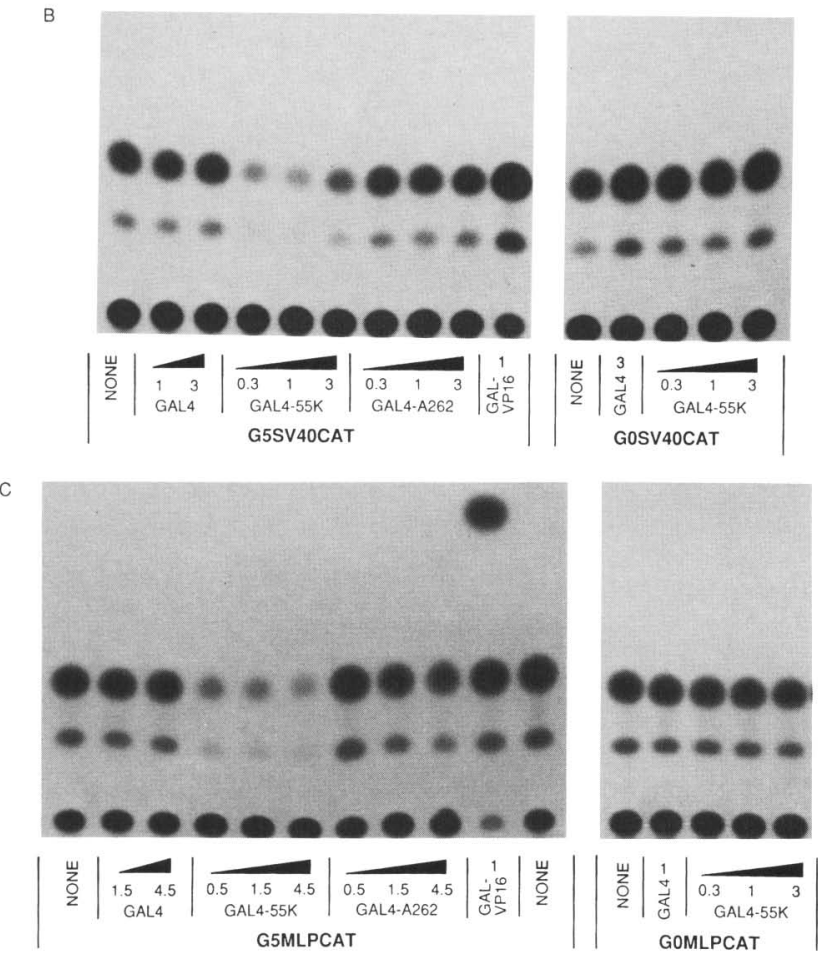

to repress transcription from the TK, MLP, and SV40 control regions. The GAL4-R443 mutant exhibited a clear defect in repression compared with wild-type GAL4-55K (Fig. 4, data for the SV40 control region not shown). This indicates that the R443 mutant is defective for the activity required to make it an effective direct repressor. However, when high concentrations of GAL4R443 plasmid DNA (>2 $\mu \mathrm{g})$ were cotransfected with G5TKCAT, the R443 defect was diminished (Fig. 5C), indicating that the mutation does not completely eliminate $55 \mathrm{~K}$ repression function.

To further characterize regions of $55 \mathrm{~K}$ required for its function as a direct transcriptional repressor, a number of deletion and insertion mutants (Fig. 5A) were analyzed as fusions to the GAL4 DNA-binding domain. Deletion mutants removing amino acids in the central portion of E1B 55K between amino acids 215 and 354 eliminated transcriptional repressing function (Fig. 5B). Deletion of
Figure 3. E1B 55K represses CAT activity from the SV40 control region and the Ad2 major late promoter. $(A)$ SV40 and MLP reporters. G5SV40CAT (top) bears five GAL4-binding sites 180 bp upstream from the SV40 enhancer and promoter or $\sim 530$ bp from the transcription initiation site. G5MLPCAT (bottom) contains five GAL4-binding sites 15 bp upstream of the MLP (including the upstream stimulating factor, CCAAT, TATA, and initiator elements) or $\sim 264$ bp from the transcription initiation site. $(B)$ SV40 control region. CAT assay showing increasing amounts of GAL4(1-147), GAL4-55K, and GAL4-A262 expression plasmids cotransfected with either $0.2 \mu \mathrm{g}$ of G5SV40CAT or $0.2 \mu \mathrm{g}$ of G0SV40CAT reporter plasmids. The amount of plasmid DNA transfected in each lane is shown below each wedge. (Left) Results with the SV40 reporter bearing five GAL4-binding sites; (right) results obtained with the SV40 reporter bearing no GAL4-binding sites. GAL4A262 expresses a GAL4 fusion protein with an E1B 55K mutant containing a 4-amino acid in-frame insertion at amino acid 262. GAL4-VP16 expresses a GAL4 fusion with the activation domain of the HSV transcriptional activator VP16. CAT activities were quantitated and are listed in order from left to right. The activity of the reporter alone (NONE) was set at 100\%. G5SV40CAT: 100, 75, $87,17,14,28,71,68,82,327$. GOSV40CAT: 100, 266, 180, 154, 260. These values are representative of at least two experiments for each sample tested. (C) MLP. CAT assay with the MLP reporter bearing five GAL4-binding sites (left) and no GAL4-binding sites (right) with increasing amounts of plasmid DNA expressing GAL4 fusion proteins with the amount of DNA transfected in micrograms shown below each wedge. Five micrograms of each reporter was transfected. CAT activities were quantitated and are listed in order from left to right. The activity of the reporter alone (NONE) was set at 100\%. G5MLPCAT: 100, 87, 77, 12, 8.5, 6.4, 119, 72, 54, 204,100 . (The two values of the reporter alone were averaged and set at $100 \%$.) GOMLPCAT: 100, 99, 90, 89, 79. These values are representative of at least two experiments for each sample tested.

amino acids 17 to 68 , removing an alanine-rich region, had a minimal effect on repression. Surprisingly, deletion of amino acids 354-443 had no effect on repression, even though an insertion of 4 amino acids at residue 443 was defective for repressing activity.

The insertion mutants defined three regions of the $55 \mathrm{~K}$ protein necessary for repression. Insertions at amino acid 180, between amino acids 262 and 326, and at amino acids 443 and 484 were all reduced for repressing activity (Fig. 5C). It was not possible to detect these GAL4-55K fusion proteins in the transfected HeLa cells. Therefore, to test whether these defects in repressing activity might be the result of instability of the GAL4 fusion proteins in mammalian cells, expression of the proteins was analyzed directly in COS cells where replication of the transfected expression vectors led to higher expression of the encoded proteins. With the exception of GAL4-F484, all of the insertion mutants accumulated to levels near 
Yew et al.

Figure 4. R443 is defective for transcriptional repression. (A) Effect of GAL4-R443 on G1TKCAT. GITKCAT was transfected at 7 $\mu \mathrm{g}$ per lane along with increasing amounts of plasmid DNA (between 0.01 and $1 \mu \mathrm{g}$ ) expressing GAL4(1-147), GAL4-55K, GAL4A262, and GAL4-R443. A262 and R443 are insertion mutants of E1B 55K. Amounts of DNA transfected for each GAL4 fusion were indicated in micrograms. CAT activities were quantitated and are listed in order from left to right. The activity of the reporter alone (NONE) was set at 100\%. G1TKCAT: 100, 86, 167, 86, 32, 27, 17, $125,118,123,170,86,85,81,42$. These values are representative of at least three experiments for each sample tested. $(B)$ GAL4R443 in CV-1 cells. CAT assay showing the effect of GAL4-R443 on the G5TKCAT reporter in CV-1 cells. GAL4 fusion plasmids 12 and $5 \mu$ ) were transfected with $7 \mu \mathrm{g}$ of G5TKCAT. GAL4 expresses amino acids 1-147, and A262 and R443 are E1B 55K insertion mutants. CAT activities were quantitated and are listed in order from left to right. The activity of the reporter alone (NONE) was set at 100\%. G5TKCAT: 100, 276, 293, 17, 18, 188, 404, 85, 89 . These values are representative of at least three experiments for each sample tested. (C) GAL4-R443 on G5MLPCAT. CAT assay with increasing amounts of GAL4-R443 on the G5MLPCAT reporter in HeLa cells. Amounts of transfected DNA are indicated in micrograms. GAL4 expresses the DNA-binding domain of GAL4(1-147) and R443 is an insertion mutant of E1B 55K. CAT activities were quantitated and are listed in order from left to right. The activity of the reporter alone (NONE) was set at $100 \%$. G5MLPCAT: $100,77,74,11,8.8,6.7,36,24,24$. These values are representative of at least two experiments for each sample tested.

or above the wild-type E1B 55K fusion. Similar results were observed for the original $55 \mathrm{~K}$ mutants (as opposed to GAL4 fusions) in Western blots of extracts from HeLa cells (Yew et al. 1990) and primary baby rat kidney cells (Yew and Berk 1992) infected with adenovirus mutants. Consequently, with the exception of GAL4-F484, the failure of GAL4-55K mutants to repress CAT expression was probably not the result of reduced protein concentrations. The 12 insertion mutants have also been tested for their ability to transform primary rodent cells in association with the adenovirus E1A proteins (Yew and

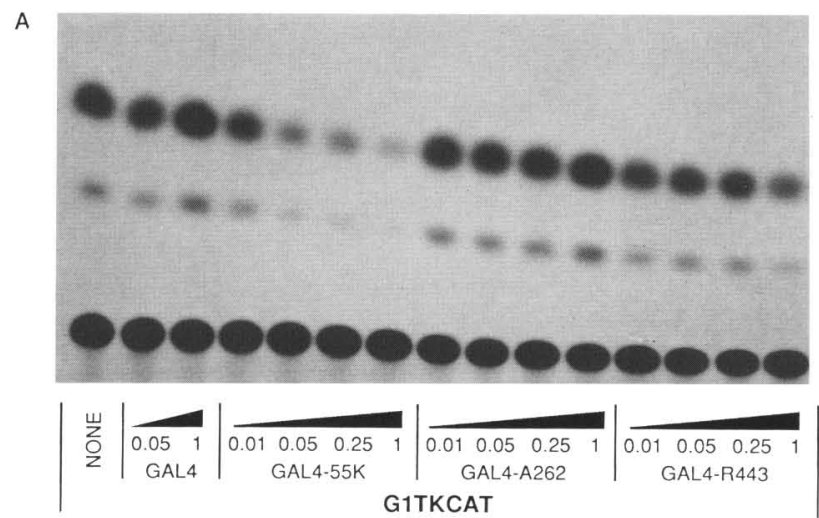

B

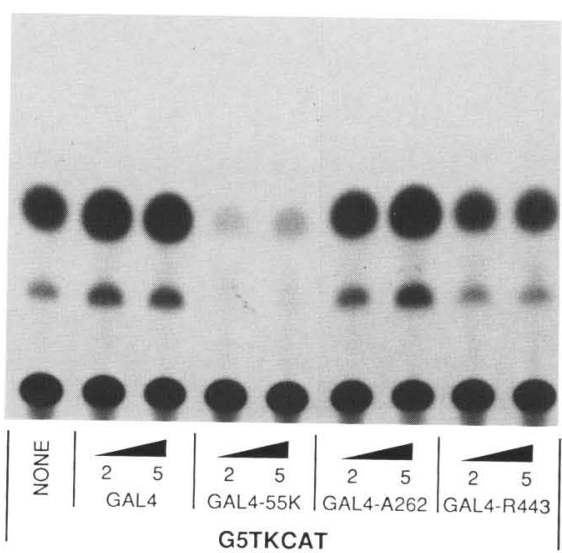

C

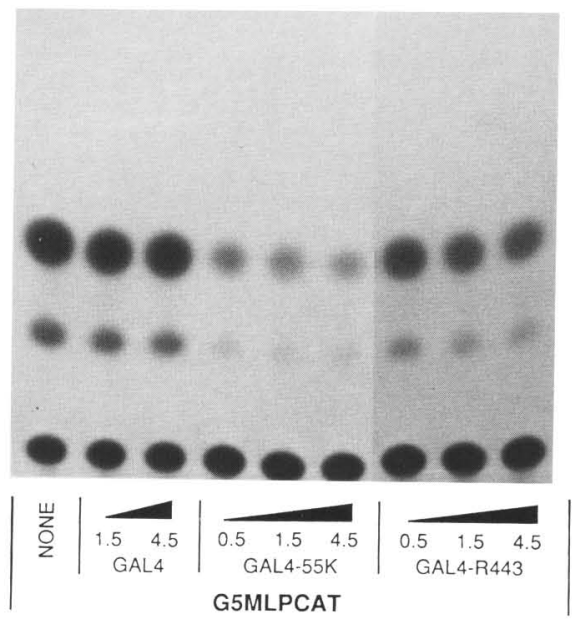

Berk 1992; Table 1). It is striking that transcriptional repression by the GAL4-55K mutants correlates precisely with the transforming activities of the equivalent $55 \mathrm{~K}$ mutants.

\section{p53 is not required for GAL4-55K transcriptional repression}

The region between residues 262 and 326 required for $55 \mathrm{~K}$ repression overlaps the region of $55 \mathrm{~K}$ required to bind p53 (Kao et al. 1990; Yew and Berk 1992; Table 1). 
A

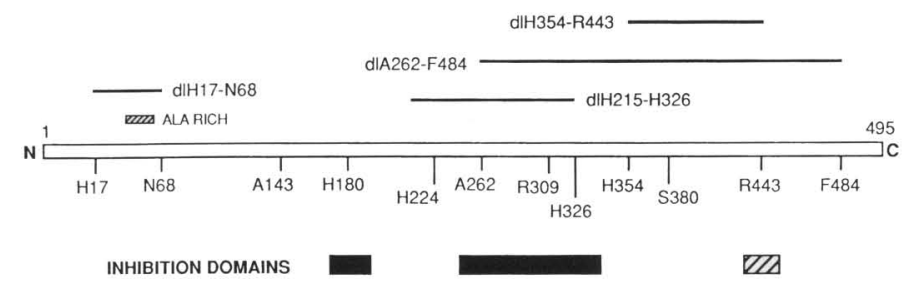

INHIBITION DOMAINS

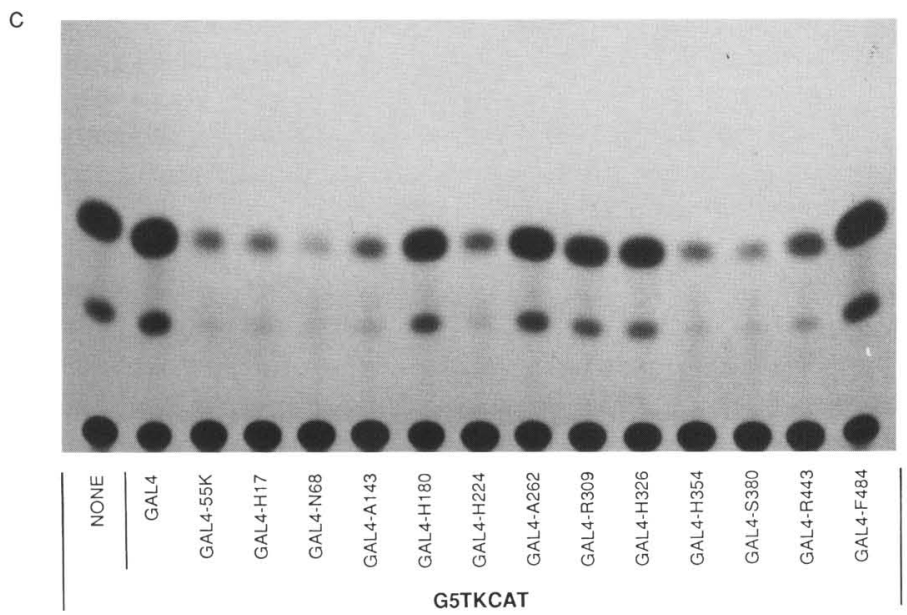

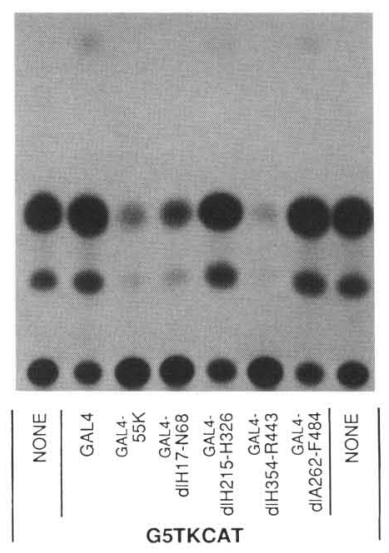
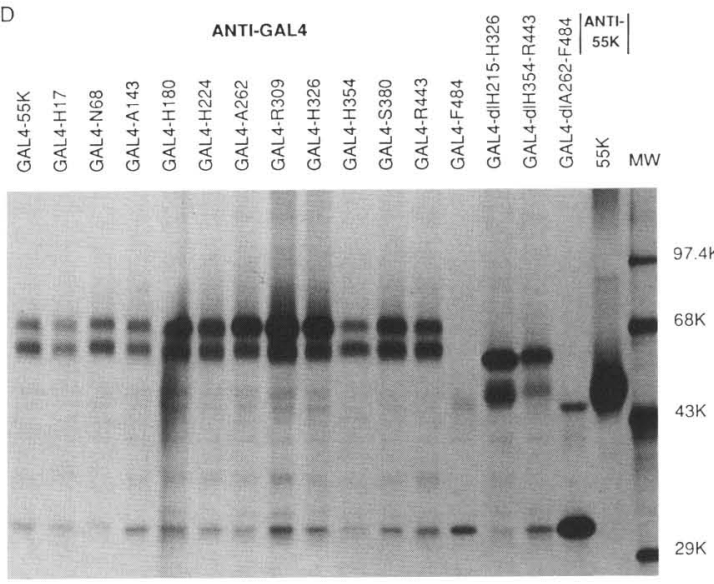

Figure 5. Regions of E1B 55K required for transcriptional repression. (A) E1B 55K insertion and deletion mutants. Schematic drawing of the E1B 55K protein from the amino terminus to the carboxyl terminus with deletion mutants diagramed above and insertion mutants indicated below. The letters represent the restriction site used to make the insertion, and the number represents the amino acid at or preceding the insertion site (Yew et al. 1990). The E1B 55K protein is 495 amino acids in length. An alanine-rich region within E1B $55 \mathrm{~K}$ is shown by the hatched rectangle between amino acids 17 and 68 . Inhibition domains are indicated: solid rectangles indicate regions of E1B $55 \mathrm{~K}$ defective when mutated; the hatched rectangle represents a region of $55 \mathrm{~K}$ defective in a concentration-dependent manner when mutated. $(B)$ E1B 55K deletion mutations. CAT assay showing the effect of different GAL4-55K deletion mutants on the G5TKCAT reporter. GAL4 fusion expression vectors were transfected at $2.5 \mu \mathrm{g}$ per lane, and G5TKCAT reporter was used at $6.5 \mu \mathrm{g}$ per lane. Deletions are named by the regions removed between two specified insertion mutants. CAT activities were quantitated and are listed in order from left to right. The two values of the reporter alone (NONE) were averaged and set at 100\%. G5TKCAT: 100, 135, $9.2,17,132,7.9,129,100$. These values are representative of at least three experiments for each sample tested. $(C)$ E1B $55 \mathrm{~K}$ insertion mutations. CAT assay with the G5TKCAT reporter and GAL4-55K insertion mutants. GAL4-55K insertion mutants are indicated by their names as shown in Fig. 5A. GAL4 fusion plasmids were transfected at $2.5 \mu \mathrm{g}$ per lane, and G5TKCAT was used at $6.5 \mu \mathrm{g}$ per lane. CAT activities were quantitated and are listed in order from left to right. The activity of the reporter alone (NONE) was set at $100 \%$. G5TKCAT: $100,157,8.4,7.3,3.7,8.5,72,8.7,90,56,56,6.9,4.6,17,182$. These values are representative of at least two experiments for each sample tested. $(D)$ Immunoprecipitation of GAL4 fusion proteins. COS cells were transfected with $5 \mu \mathrm{g}$ of GAL4 fusion constructs per sample, and cells were metabolically labeled. Double immunoprecipitations were carried out with either a rabbit antiserum against GAL4 shown at left or with the anti-55K monoclonal antibody $2 \mathrm{~A} 6$ at right. ${ }^{14} \mathrm{C}$-Labeled molecular weight markers are indicated at right.

This raised the possibility that $\mathrm{p} 53$ might be involved in GAL4-55K repression. To test this possibility, we assayed the ability of GAL4- $55 \mathrm{~K}$ to repress CAT activity from the TK promoter in two p53-minus cell lines. The Saos-2 and (10)1 cell lines have large deletions in their p53-coding regions and express no p53 mRNA or protein (Masuda et al. 1987; Harvey and Levine 1991). GAL4 $55 \mathrm{~K}$ protein retained the ability to efficiently repress
CAT expression from the TK promoter in these cell lines (Fig. 6), demonstrating that p53 is not required for transcriptional repression by GAL4-55K.

\section{Discussion}

A model for E1B $55 \mathrm{~K}$ repression of p53-activated genes

E1B $55 \mathrm{~K}$ inhibits transcriptional activation by $\mathrm{p} 53$, a 
Yew et al.

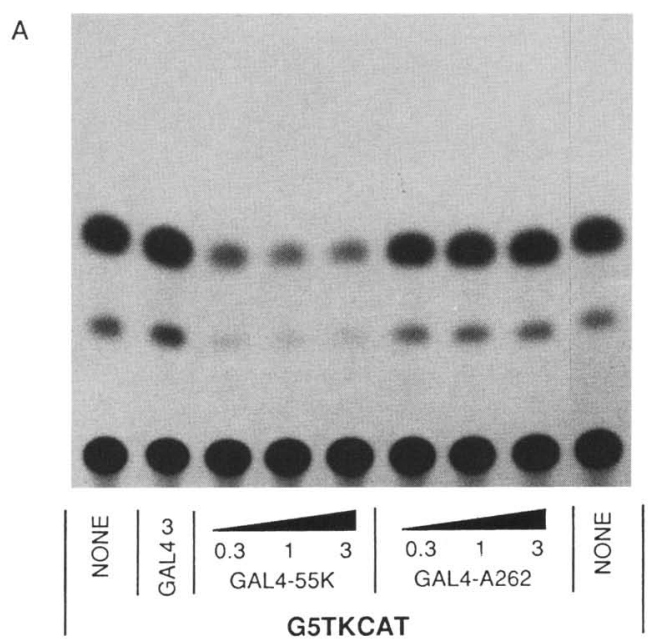

B

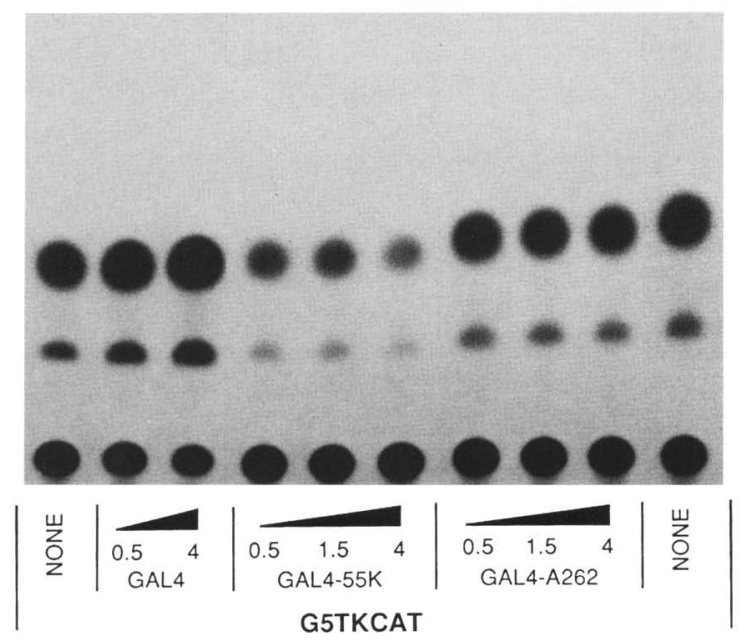

Figure 6. $\mathrm{p} 53$ is not required for GAL4-55K transcriptional repression. (A) Saos-2 cells. CAT assay using the G5TKCAT reporter at $7 \mu \mathrm{g}$ per sample with increasing amounts of GAL455K and GAL4-A262 (0.3 to $3 \mu \mathrm{g})$. GAL4 represents the DNA binding domain of GAL4(1-147), and A262 is an E1B 55K insertion mutant. Saos- 2 cells are defective for expression of p53 protein. CAT activities were quantitated and are listed in order from left to right. The two values of the reporter alone (NONE) were averaged and set at 100\%. G5TKCAT: 100, 158, 22, 17, 18, $78,98,100,100$. These values are representative of at least three experiments for each sample tested. $(B)(10) 1$ cells. CAT assay showing the effect of increasing amounts of GAL4, GAL4-55K, and GAL4-A262 (0.5 to $4 \mu \mathrm{g})$ on the G5TKCAT reporter $(7 \mu \mathrm{g})$ bearing five GAL4-binding sites. GAL4 expresses only the DNA binding domain (1-147), and A262 is an E1B 55K insertion mutant. (10) 1 cells do not express any p53 protein. CAT activities were quantitated and are listed in order from left to right. The two values of the reporter alone (NONE) were averaged and set at 100\%. G5TKCAT: 100, 167, 288, 29, 33, 19, 90, 86, 80, 100. These values are representative of at least two experiments for each sample tested.

function required for $\mathrm{E} 1 \mathrm{~B} 55 \mathrm{~K}$ transforming activity (Yew and Berk 1992). The results reported here demonstrate that E1B 55K forms a complex with p53 without displacing $\mathrm{p} 53$ from its specific DNA-binding site (Fig.
1). Furthermore, we found that $55 \mathrm{~K}$ contains a potent transcriptional repression domain because a GAL4-E1B $55 \mathrm{~K}$ fusion protein represses expression of reporter genes when bound within a few hundred bases of their transcription initiation site (Figs. 2 and 3). These results suggest the model shown in Figure 7. In this model the repression domain of E1B 55K inhibits the activity of a general transcription factor required for initiation by RNA polymerase II, or the polymerase itself. This repression domain is targeted to promoters activated by p 53 through the specific p53-binding activity of E1B 55K first observed by Sarnow et al. (1982a). Strong support for this model comes from the perfect correlation between the effect of E1B 55K mutations on 55K transforming activity and on the transcriptional repression activity of the GAL4-55K fusion (Table 1). These results indicate that the E1B 55K protein contributes to adenovirus transformation by functioning as a direct transcriptional repressor targeted to p53-activated genes. It is also possible that the E1B 55K repression domain is targeted to additional DNA sites by binding to transcription factors other than p53.

\section{Comparison of E1B $55 \mathrm{~K}$ to other eukaryotic repressors}

The E1B 55K protein appears to function as a direct transcriptional repressor (Levine and Manley 1989) in a manner similar to several other proteins with transcriptional repressing activity from different eukaryotes: yeast $\alpha 2-$ Mcml (Johnson and Herskowitz 1985), yeast proteins interacting with the silent mating-type loci silencers (Brand et al. 1985), the human thyroid receptor in the absence of hormone (Damm et al. 1989), the Drosophila

A

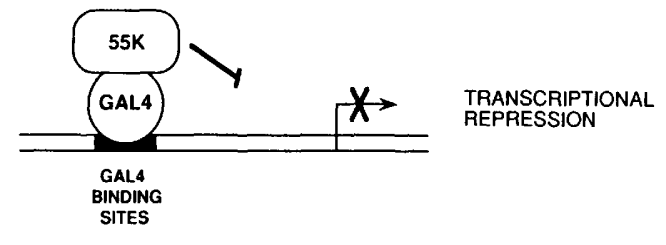

B

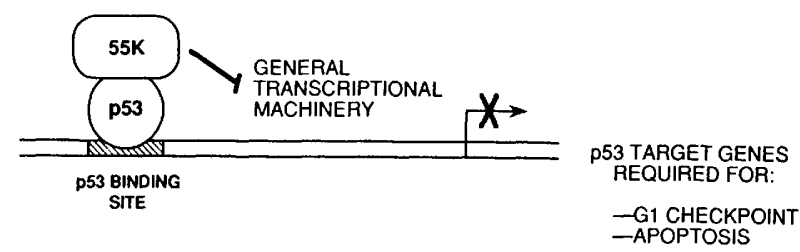

Figure 7. Model for E1B 55K inhibition of p53-mediated transcriptional activation. $(A)$ When E1B $55 \mathrm{~K}$ is directly brought to a promoter bearing GAL4 sites by the DNA-binding domain of GAL4, 55K mediates transcriptional repression on heterologous promoters. $(B) \mathrm{E} 1 \mathrm{~B} 55 \mathrm{~K}$ is directed to a promoter by specific binding to p53. E1B $55 \mathrm{~K}$ then mediates transcriptional repression by modifying the general transcriptional machinery, repressing p53 target genes. In this way, E1B $55 \mathrm{~K}$ would specifically inhibit transcription of p53-responsive genes that may be required for the correct implementation of $\mathrm{a}_{1}$ checkpoint and/ or apoptosis. 
Krüppel protein (Licht et al. 1990), and other eukaryotic "direct repressors" that have been described (see Han and Manley 1993|. Each of these proteins can repress promoters they do not normally regulate when their binding sites are placed within a few hundred base pairs of the transcription initiation site. E1B $55 \mathrm{~K}$ is distinct from these in that it does not bind DNA directly. It may be similar in this regard to the complex of yeast Ssn6 and Tupl required for repression by the DNA-binding proteins $\alpha 2-\mathrm{Mcm} 1$, al $-\alpha 2$, and Migl (Keleher et al. 1992). In the case of E1B 55K, the specific binding of E1B 55K to p53 tethers the potent transcriptional repression domain of E1B 55K to promoters with p53-binding sites.

We suggested that E1B 55K inhibits the activity of a general transcription factor because the GAL4-55K fusion repressed transcription from three different promoters with no single activator in common. Transcriptional repressing domains from Drosophila even-skipped protein (Han and Manley 1993) and mammalian thyroid and retinoic acid receptors (Baniahmad et al. 1992) also probably target a general transcription factor because they repress transcription from minimal promoters consisting of only a TATA box or initiator element. The target of repression could equally well be the polymerase itself. This possibility has been raised for the yeast repressor Sinl (Spt2) because a genetic interaction has been reported between Sinl and the carboxy-terminal repeat of the large subunit of RNA polymerase II (Peterson et al. 1991).

We cannot tell from these in vivo experiments whether E1B $55 \mathrm{~K}$ represses transcription directly or whether additional factors interacting with $55 \mathrm{~K}$ are required. As mentioned above, in yeast it appears that repression by the DNA-binding proteins $\alpha 2-\mathrm{Mcm} 1$, al- $-\alpha 2$, and Migl require that these factors bind an additional complex of the Ssn6 and Tup1 proteins (Keleher et al. 1992). The finding that high levels of GAL4-55K reproducibly diminished repression of the SV40 early promoter and enhancer compared with lower GAL4-55K concentrations (Fig. 3B) might be explained by the titration of similar "corepressors" required for $55 \mathrm{~K}$ repression. This "squelching" of repression might be analogous to the squelching of activation by high concentrations of activators (Gill and Ptashne 1988).

Other transcriptional repression domains have been shown to be alanine rich (Licht et al. 1990), highly basic (Baniahmad et al. 1992; Saha et al. 1993), and rich in proline and hydrophobic residues (Madden et al. 1991; Han and Manley 1993). E1B 55K contains an alanine-rich region between amino acids 47 and $60 / 8$ of 14 residues are alanine). However, deletion of this region from GAL4-55K had only a small effect on repressing activity (Fig. 5). The regions of E1B 55K where deletions and insertions did interfere with repression are neither highly basic nor proline rich. The central region of $55 \mathrm{~K}$ spanning amino acids $\sim 250-350$, where three insertions inactivated repression by GAL4-55K, does contain a high proportion of hydrophobic amino acids. However, these insertions may disrupt the tertiary structure of the protein because they also inhibit $\mathrm{p} 53$ binding by $55 \mathrm{~K}$ and an apparently distinct function of the E1B $55 \mathrm{~K}$ protein involved in the preferential nuclear-cytoplasmic transport of viral mRNAs during the late phase of infection (Yew et al. 1990; see Ornelles and Shenk 1991).

\section{p53 is not required for GAL4-55K repression}

Not surprisingly, the regions of E1B $55 \mathrm{~K}$ required to inhibit p53-mediated transcriptional activity included a region required for p53 binding (Yew and Berk 1992). In analyzing regions of $55 \mathrm{~K}$ required for repression by the GAL4-55K fusion, we did not expect to observe a requirement for the p53-binding domain. We anticipated that this function would be replaced by the GAL4 DNAbinding domain. Surprisingly, all the insertion mutations analyzed that disrupt E1B 55K-p 53 binding also inactivated repression by GAL4-55K. This raised the question of whether p53 was a cofactor required for GAL4-55K repression. p53 itself may mediate transcriptional repression of promoters containing CCAAT boxes by interacting with the CCAAT-binding factor (Agoff et al. 1993). It has also been suggested that p53 may repress transcription by its interaction with TBP (Seto et al. 1992; Mack et al. 1993). Overexpressed p53 has also been shown to reduce the transcriptional activity of a number of promoters that do not contain consensus p53-binding sites (Ginsberg et al. 1991). Despite the many reasons for considering that p53 might be required for transcriptional repression by GAL4-55K, we found that GAL4$55 \mathrm{~K}$ continued to repress expression from target promoters in cells completely lacking p53. Further studies of E1B $55 \mathrm{~K}$ as a transcriptional repressor should add to the limited but growing knowledge concerning direct transcriptional repressors or silencers and the mechanism by which they repress transcription.

\section{Materials and methods \\ Cell culture, transfection, and CAT assay}

HeLa and CV-1 cells were grown in Dulbecco's modified Eagle medium (DMEM) supplemented with $10 \%$ newborn calf serum and $5 \%$ fetal calf serum (FCS), respectively and were transfected as described previously (Yew and Berk 1992). Saos-2 (Masuda et al. 1987), and (10)1 (Harvey and Levine, 1991) cells were grown in DMEM supplemented with $10 \%$ FCS and transfected as described (Zambetti et al. 1992). Cells were harvested $48 \mathrm{hr}$ posttransfection. The amount of reporter plasmid transfected was as follows: $6.5-7 \mu \mathrm{g}$ of TKCAT reporters, $0.2 \mu \mathrm{g}$ of SV40CAT reporters, and $5 \mu \mathrm{g}$ of MLPCAT reporters. All samples for CAT assays were normalized for $\beta$-galactosidase activity expressed from a cotransfected control expression vector and used in CAT assays as described (Yew and Berk 1992).

\section{Vaccinia virus construction and p53 purification}

pTM.1-ep53, expressing epitope-tagged p53, was constructed by PCR amplification of human p53 from the pcDNA-p53 plasmid (Liu et al. 1993), using primers that introduce an NcoI site and the amino acid sequence MYPYDVPDYA at the $5^{\prime}$ end, and a BamHI site at the $3^{\prime}$ end. The amplified DNA fragments were cloned between the NcoI and BamHI sites of the pTM.1 vector 
(Elroy-Stein et al. 1989). Recombinant vaccinia virus expressing epitope-tagged human p53 was constructed by the procedure of Elroy-Stein et al. (1989). Correct recombinant vaccinia virus was confirmed by Western blot analysis of cell extracts prepared from infected cells. Recombinant virus (VV-ep53) was plaque purified, viral stocks were grown, and viral titers were determined by plaque assay on HeLa cells.

Epitope-tagged p53 was affinity-purified from vaccinia virusinfected HeLa cells. Two liters of Hela cells were infected with recombinant viruses VV-ep53 and v-TF7-3 (which expresses T7 RNA polymerase|, each at am m.o.i. of five. Cells were harvested at $24 \mathrm{hr}$ postinfection and nuclear extract was prepared (Dignam et al. 1983). One milliliter of the nuclear extract was incubated with $150 \mu \mathrm{l}$ of packed beads of protein A-Sepharose covalently coupled to monoclonal antibody $12 \mathrm{CA} 5$ at $4^{\circ} \mathrm{C}$ for 6 hr (Liu et al. 1993). The 12CA5 affinity beads were washed three times with $0.4 \mathrm{M} \mathrm{KCl} \mathrm{D} \mathrm{buffer} \mathrm{(20} \mathrm{mM} \mathrm{HEPES,} \mathrm{20 \%} \mathrm{glycerol,} 0.2$ mM EDTA, $1 \mathrm{mM}$ dithiothreitol, $1 \mathrm{mM}$ PMSF/ and two times with $0.1 \mathrm{M} \mathrm{KCl} \mathrm{D}$ buffer. ep53 was eluted with $60 \mu \mathrm{l}$ of the influenza virus epitope oligopeptide (YPYDVPDYA) at $1 \mathrm{mg} / \mathrm{ml}$ in $0.1 \mathrm{M} \mathrm{KCl} \mathrm{D}$ buffer.

\section{Plasmid construction}

The in vitro translation vectors expressing wild-type E1B $55 \mathrm{~K}$ and H326 were constructed by cloning the 1865 -bp SstI fragment from pUC19.R-/Ad1767-3632 (Yew et al. 1990) into the SstI site of pSP65. The in vitro translation vector for R443 was constructed by cloning the 1720-bp BstEII-BamHI fragment from pSR $\alpha-R 443$ (Yew and Berk 1992) with the 3150-bp BstEIIBamHI fragment from pSP65/55K. The GAL4-55K-expressing plasmid was constructed by cloning a BamHI-SstI E1B 55K PCR fragment into the BamHI-SstI sites of the plasmid, pSG424 (Sadowski and Ptashne 1989) to make pSG424/55K PCR. This construct was sequenced through the GAL4 fusion region and beyond the $A s p 718$ site in the adenovirus E1B $55 \mathrm{~K}$ sequence (Ad2 sequence 2045). GAL4 fusion constructs were then made for wild-type E1B 55K, and $55 \mathrm{~K}$ mutants $\mathrm{H} 17, \mathrm{~N} 68, \mathrm{Al} 43, \mathrm{H} 180$, H224, A262, R309, H326, H354, S380, R443, F484, dlH354 R443, dlA262-F484, dlH215-H326, dlH17-N68 by cloning the Asp718-SstI 1600-bp fragment from pAd2.17.R/CA-/19K ${ }^{-} 55 \mathrm{~K}$ mutants and wild type (Yew and Berk 1992) between the Asp718 and SstI sites of pSG424/55K PCR.

The CAT reporter plasmids were constructed as follows: The GOTKCAT and GITKCAT plasmids were constructed by cloning the GAL4-containing XbaI-SstI fragments from G0E4TATA/pGEM-3 or G1E4TATA/pGEM-3, respectively, between the XbaI and SstI sites of G5TKCAT (Shi et al. 1991). G5SV40CAT was constructed by cloning an end-filled $\mathrm{Xbal}-$ HindIII 100-bp fragment containing five GAL4-binding sites from G5E4TATA/pGEM-3 into the filled-in AccI site (SV40 520 bp) of pSV2CAT (Gorman et al. 1982) that contains the entire SV40 enhancer and early promoter from SV40 340 bp to SV40 $5018 \mathrm{bp}$. The G5MLPCAT plasmid was constructed by cloning a 250-bp XbaI-XhoI PCR fragment containing the MLP from Ad2 5790 bp to Ad2 6062 bp between the $X b a I$ and $X h o I$ sites of G5TKCAT, substituting the Ad2 MLP for the 150-bp TK promoter region.

Oligonucleotides containing one p53-binding site were made as complementary 24 -mers containing one RGC site $15^{\prime}-\mathrm{CT}$ TGCCTGGACTTGCCTGG) with a XhoI site at the $5^{\prime}$ end and a Sall site at the $3^{\prime}$ end. The plasmid pB5E4T was constructed by ligating five tandem p53-binding oligonucleotides into the SalI site of $\mathrm{p} \Delta-38,23 \mathrm{bp}$ upstream from the E4 TATA box (Carey et al. 1990).

\section{Immunoblotting and immunoprecipitation}

Immunoblotting was performed on in vitro-translated proteins by the method described previously (Yew and Berk 1992) using anti-55K 2A6 (Sarnow et al. 1982b) hybridoma supernatant diluted 1:10. For the immunoprecipitation, COS cells were labeled with Trans ${ }^{35} \mathrm{~S}$-label $60 \mathrm{hr}$ post-transfection for $2.5 \mathrm{hr}$ and were then harvested in $10 \mathrm{~S}$ buffer [ $250 \mathrm{~mm} \mathrm{NaCl}, 50 \mathrm{mM}$ HEPES (pH 7.2), $0.3 \%$ NP-40, $0.1 \%$ Triton X-100, and $0.005 \%$ SDS]. The extracts were precipitated with trichloroacetic acid (TCA), and $5 \times 10^{7}$ TCA-precipitable counts were used for each sample with $1 \mu \mathrm{l}$ of anti-GAL4 antibody using a double immunoprecipitation protocol (Yew and Berk 1992).

\section{DNA immunoprecipitation}

The DNA immunoprecipitation assay was performed essentially as described with modifications (Kern et al. 1991). A 160bp HindIII-XbaI DNA fragment containing five RGC sites from the pB5E4T plasmid was used. The RGC fragment was ${ }^{32} \mathrm{P}$ labeled by end-filling, and $5 \times 10^{5} \mathrm{cpm}$ of probe was used in each reaction. DNA probe, $20 \mu \mathrm{l}$ of purified $\mathrm{p} 53$ from vaccinia virus, and $125 \mu \mathrm{l}$ of in vitro-translated E1B $55 \mathrm{~K}$ protein were incubated for $1 \mathrm{hr}$ at $30^{\circ} \mathrm{C}$ in $200 \mu \mathrm{l}$ with $50 \mathrm{ng} / \mu \mathrm{l}$ of poly[d(I-C)] in binding buffer (Kern et al. 1991). Protein A-Sepharose was incubated with $600 \mu \mathrm{l}$ of hybridoma supernatants pAb421 (Harlow et al. 1981) or $2 \mathrm{~A} 6$ for $1.5 \mathrm{hr}$ at room temperature and was washed twice with binding buffer. The antibody bound to protein A-Sepharose was mutated with the DNA, p53, and E1B $55 \mathrm{~K}$ mixture for $1 \mathrm{hr}$ at room temperature. The reaction was washed twice with binding buffer, processed as described (Kern et al. 1991), and analyzed by electrophoresis in a 5\% polyacrylamide TBE gel, followed by autoradiography.

\section{EMSA}

The 160-bp DNA fragment used in the mobility-retardation assay was cut from pB5E4T using BamHI and HindIII and was ${ }^{32}$-end-labeled with T4 polynucleotide kinase. Purified ep53 protein $(1 \mu$ l) was added to unprogrammed reticulocyte lysate or in vitro-translated ElB $55 \mathrm{~K}$ protein $(1,2$, or $4 \mu \mathrm{l})$ and incubated with $1000 \mathrm{cpm}$ of ${ }^{32} \mathrm{P}$-labeled DNA probe in mobility-shift buffer $160 \mathrm{mM} \mathrm{KCl}, 12 \%$ glycerol, $5 \mathrm{~mm} \mathrm{MgCl}, 1 \mathrm{~mm}$ EDTA, 10 $\mathrm{mg} / \mathrm{ml}$ of poly[d(GC)] at $30^{\circ} \mathrm{C}$ for $40 \mathrm{~min}$. Purified ep53 alone did not produce as intense a mobility-shift signal as when either $50 \mu \mathrm{g} / \mathrm{ml}$ of BSA or reticulocyte lysate was added with the purified p53 to provide carrier proteins. Samples were analyzed on a $1.4 \%$ agarose gel containing $0.5 \times$ TBE $\mid 0.045 \mathrm{~mm}$ Tris-borate, $0.045 \mathrm{~mm}$ sodium borate, $0.001 \mathrm{~mm}$ EDTA).

\section{Acknowledgments}

We thank Randy Moore for constructing pTM.1-ep53 and C. Cheng Kao for constructing pSP65-55K and pSP65-H326, Yang Shi and Thomas Shenk for G5TKCAT, Arnold Levine for Saos-2 and (10)1 cells, and Carol Eng for help with cell culture. We are grateful to Arnold Levine, Levine laboratory members, and Thomas Boyer for helpful discussions, and to Noelle L'Etoile for helping to quantitate data. We thank Owen Witte and Stephen Smale for criticism of the manuscript. P.R.Y. was partially supported by a U.S. Public Health Service National Research Service Award predoctoral genetics training fellowship. X.L. is supported by postdoctoral fellowship DRG 1116 from the Damon Runyon-Walter Winchell Cancer Research fund. This work was supported by grant PO1 CA 32737 from the National Cancer Institute. 
The publication costs of this article were defrayed in part by payment of page charges. This article must therefore be hereby marked "advertisement" in accordance with 18 USC section 1734 solely to indicate this fact.

\section{References}

Agoff, S.N., J. Hou, D.I.H. Linzer, and B. Wu. 1993. Regulation of the human hsp 70 promoter by p53. Science 259: 84-87.

Bargonetti, J., I. Reynisdottir, P.N. Friedman, and C. Prives. 1992. Site-specific binding of wild-type p53 to cellular DNA is inhibited by SV40 T antigen and mutant p53. Genes \& Dev. 6: 1886-1898.

Baniahmad, A., A.C. Kohne, and R. Renkawitz. 1992. A transferable silencing domain is present in the thyroid hormone receptor, in the v-erbA oncogene product and in the retinoic acid receptor. EMBO J. 11: 1015-1023.

Brand, A.H., L. Breeden, J. Abraham, R. Sternglanz, and K. Nasmyth. 1985. Characterization of a "silencer" in yeast: A DNA sequence with properties opposite to those of a transcriptional enchancer. Cell 41: 41-48.

Carey, M., J. Leatherwood, and M. Ptashne. 1990. A potent GAL4 derivative activates transcription at a distance in vitro. Science 247: 710-712.

Clarke, A.R., C.A. Purdie, D.J. Harrison, R.G. Morris, C.C. Bird, M.L. Hooper, and A.H. Wyllie. 1993. Thymocyte apoptosis induced by p53-dependent and -independent pathways. $\mathrm{Na}$ ture 362: 849-852.

Damm, K., C.C. Thomson, and R.M. Evans. 1989. Protein encoded by v-erbA functions as a thyroid-hormone receptor antagonist. Nature 339: 593-597.

Dignam, J.D., R.M. Lebovitz, and R.G. Roeder. 1983. Accurate transcript initiation by RNA Pol II in a soluble extract from isolated mammalian nuclei. Nucleic Acids Res. 11: 14751489.

Diller, L., J. Kassel, C.E. Nelson, M.A. Gryka, G. Litwak, M. Gebhardt, B. Bressac, M. Ozturk, S.J. Baker, B. Vogelstein, and S.H. Friend. 1990. p53 functions as a cell cycle control protein in osteosarcomas. Mol. Cell. Biol. 10: 5772-5781.

Elroy-Stein, O., T.R. Fuerst, and B. Moss. 1989. Cap-independent translation of mRNA conferred by encephalomyocarditis virus $5^{\prime}$ sequence improves the performance of the vaccinia virus/bacteriophage T7 hybrid expression system. Proc. Natl. Acad. Sci. 86: 6126-6130.

Gill, G. and M. Ptashne. 1988. Negative effect of the transcriptional activator GAL4. Nature 334: 721-724.

Ginsberg, D., F. Mechta, M. Yaniv, and M. Oren. 1991. Wildtype p53 can down-modulate the activity of various promoters. Proc. Natl. Acad. Sci. 88: 9979-9983.

Gorman, C.M., L.F. Moffat, and B.H. Howard. 1982. Recombinant genomes which express chloramphenicol acetyltransferase in mammalian cells. Mol. Cell. Biol. 2: 1044-1051.

Han, K. and J.L. Manley. 1993. Transcriptional repression by the Drosophila even-skipped protein: Definition of a minimal repression domain. Genes \& Dev. 7: 491-503.

Farmer, G., J. Bargonetti, H. Zhu, P. Friedman, R. Prywes, and C. Prives. 1992. Wild-type p53 activates transcription in vitro. Nature 358: 83-86.

Harlow, E., L.V. Crawford, D.C. Pim, and N.M. Williamson. 1981. Monoclonal antibodies specific for simian virus $40 \mathrm{tu}$ mor antigens. J. Virol. 39: 861-869.

Hartwell, L. 1992. Defects in a cell cycle checkpoint may be responsible for the genomic instability of cancer cells. Cell 71: 543-546.

Harvey, D.M. and A.J. Levine. 1991. p53 alteration is a common event in the spontaneous immortalization of primary BALB/c murine embryo fibroblasts. Genes \& Dev. 5: 23752385.

Johnson, A.D. and I. Herskowitz. 1985. A repressor (MAT $\alpha 2$ product) and its operator control expression of a set of cell type specific genes in yeast. Cell 42: 237-247.

Kao, C.C., P.R. Yew, and A.J. Berk. 1990. Domains required for in vitro association between the cellular p53 and the adenovirus 2 E1B 55K proteins. Virology 179: 806-814.

Kastan, M.B., Q. Zhan, W.S. El-Deiry, F. Carrier, T. Jacks, W.V. Walsh, B.S. Plunkett, B. Vogelstein, and A.J. Fornace Jr. 1992. A mammalian cell cycle checkpoint pathway utilizing p53 and GADD45 is defective in ataxia-telangiectasia. Cell 71: 587-597.

Keleher, C.A., M.J. Redd, J. Schultz, M. Carlson, and A.D. Johnson. 1992. Ssn6-Tupl is a general repressor of transcription in yeast. Cell 68: 709-719.

Kern, S.E., K.W. Kinzler, A. Bruskin, D. Jarosz, P. Friedman, C. Prives, and B. Vogelstein. 1991. Identification of p53 as a sequence-specific DNA-binding protein. Science 252: 17081711.

Kern, S.E., J.A. Pietenpol, S. Thiagalingam, A. Seymour, K.W. Kinzler, and B. Vogelstein. 1992. Oncogenic forms of p53 inhibit p53-regulated gene expression. Science 256: 827 830.

Lane, D.P. 1992. p53, guardian of the genome. Nature 358: 1516.

- 1993. A death in the life of p53. Nature 362: 786-787.

Levine, A.J., J. Momand, and C.A. Finlay. 1991. The p53 tumor suppressor gene. Nature 351: 453-456.

Levine, M. and J.L. Manley. 1989. Transcriptional repression of eukaryotic promoters. Cell 59: 405-408.

Licht, J.D., M.J. Grossel, J. Figge, and U.M. Hansen. 1990. Drosophila kruppel protein is a transcriptional repressor. Nature 346: 76-79.

Lin, D., M.T. Shields, S.J. Ullrich, E. Appella, and W.E. Mercer. 1992. Growth arrest induced by wild-type $\mathrm{p} 53$ protein blocks cells prior to or near the restriction point in late G1 phase. Proc. Natl. Acad. Sci. 89: 9210-9214.

Liu, X., C.W. Miller, P.H. Koeffler, and A.J. Berk. 1993. The p53 activation domain binds the TATA box-binding polypeptide in holo-TFIID, and a neighboring p53 domain inhibits transcription. Mol. Cell. Biol. 13: 3291-3300.

Livingstone, L.R., A. White, J. Sprouse, E. Livanos, T. Jacks, and T.D. Tlsty. 1992. Altered cell cycle arrest and gene amplification potential accompany loss of wild-type p53. Cell 70: $923-935$

Lowe, S.W., E.M. Schmitt, S.W. Smith, B.A. Osborne, and T. Jacks. 1993. p53 is required for radiation-induced apoptosis in mouse thymocytes. Nature 362: 847-849.

Mack, D.H., J. Vartikar, J.M. Pipas, and L.A. Laimins. 1993. Specific repression of TATA-mediated but not initiator-mediated transcription by wild-type p53. Nature 363: 281-283.

Madden, S.L., D.M. Cook, J.F. Morris, A. Gashler, V.P. Sukhatme, and F.J. Rauscher III. 1991. Transcriptional repression mediated by the WT1 Wilms tumor gene product. Science 253: 1550-1553.

Martin, K.J., J.W. Lillie, and M.R. Green. 1990. Evidence for an interaction of different eukaryotic transcriptional activators with distinct cellular targets. Nature 346: 147-152.

Masuda, H., C. Miller, P. Koeffler, H. Battifora, and M.J. Cline. 1987. Rearrangement of the p53 gene in human osteogenic sarcomas. Proc. Natl. Acad. Sci. 84: 7716-7719.

Momand, J., G.P. Zambetti, D.C. Olson, D. George, and A.J. Levine. 1992. The mdm-2 oncogene product forms a complex with the p53 protein and inhibits p53-mediated trans- 
Yew et al.

activation. Cell 69: 1237-1245.

Oliner, J.D., J.A. Pietenpol, S. Thiagalingam, J. Gyuris, K.W. Kinzler, and B. Vogelstein. 1993. Oncoprotein MDM2 conceals the activation domain of tumour suppressor p53. $\mathrm{Na}$ ture 362: 857-860.

Ornelles, D.A. and T. Shenk. 1991. Localization of the adenovirus early region 1B 55-kilodalton protein during lytic infection: Association with nuclear viral inclusions requires the early region 4 34-kilodalton protein. J. Virol. 65: 424 439.

Peterson, C.L., W. Kruger, and I. Herskowitz. 1991. A functional interaction between the C-terminal domain of RNA polymerase II and the negative regulator SIN1. Cell 64: 11351143.

Renkawitz, R. 1990. Transcriptional repression in eukaryotes. Trends Genet. 6: 192-197.

Sadowski, I. and M. Ptashne. 1989. A vector for expressing GAL4(1-147) fusions in mammalian cells. Nucleic Acids Res. 17: 7539.

Saha, S., J.M. Brickman, N. Lehming, and M. Ptashne. 1993. New eukaryotic transcriptional repressors. Nature 363: 648-652.

Sarnow, P., Y.S. Ho, J. Williams, and A.J. Levine. 1982a. Adenovirus Elb-58kd tumor antigen and SV40 large tumor antigen are physically associated with the same $54 \mathrm{kd}$ cellular protein in transformed cells. Cell 28: 387-394.

Sarnow, P., C.A. Sullivan, and A.J. Levine. 1982b. A monoclonal antibody detecting the adenovirus type $5 \mathrm{Elb}-58 \mathrm{Kd}$ tumor antigen: Characterization of the Elb-58Kd tumor antigen in adenovirus-infected and -transformed cells. Virology 120: $510-517$.

Scheffner, M., B.A. Werness, J.M. Huibregtse, A.J. Levine, and P.M. Howley. 1990. The E6 oncoprotein encoded by human papillomavirus types 16 and 18 promotes the degradation of p53. Cell 63: 1129-1136.

Seto, E., A. Usheva, G.P. Zambetti, J. Momand, N. Horikoshi, R. Weinmann, A.J. Levine, and T. Shenk. 1992. Wild-type p53 binds to the TATA-binding protein and represses transcription. Proc. Natl. Acad. Sci. 89: 12028-12032.

Shaw, P., R. Bovey, S. Tardy, R. Sahli, B. Sordat, and J. Costa. 1992. Induction of apoptosis by wild-type p53 in a human colon tumor-derived cell line. Proc. Natl. Acad. Sci. 89: 4495-4499.

Shi, Y., E. Seto, L.-S. Chang, and T. Shenk. 1991. Transcriptional repression by YY1, a human GLI-kruppel-related protein, and relief of repression by adenovirus ElA protein. Cell 67: 377-388.

Truant, R., H. Xiao, J. Ingles, and J. Greenblatt. 1993. Direct interaction between the transcriptional activation domain of human $\mathrm{p} 53$ and the TATA box-binding protein. I. Biol. Chem. 268: 2284-2287.

Vogelstein, B. and K.W. Kinzler. 1992. p53 function and dysfunction. Cell 70: 523-526.

Yew, P.R. and A.J. Berk. 1992. Inhibition of p53 transactivation required for transformation by adenovirus early $1 \mathrm{~B}$ protein. Nature 357: 82-85.

Yew, P.R., C.C. Kao, and A.J. Berk. 1990. Dissection of functional domains in the adenovirus 2 early 1B $55 \mathrm{~K}$ polypeptide by suppressor-linker insertional mutagenesis. Virology 179: 795-805.

Yin, Y., M.A. Tainsky, F.Z. Bischoff, L.C. Strong, and G.M. Wahl. 1992. Wild-type p53 restores cell cycle control and inhibits gene amplification in cells with mutant $\mathrm{p} 53$ alleles. Cell 70: 937-948.

Zambetti, G.P., J. Bargonetti, K. Walker, C. Prives, and A.J. Levine. 1992. Wild-type p53 mediates positive regulation of gene expression through a specific DNA sequence element. Genes \& Dev. 6: 1143-1152.

Zantema, A., P.O. Schrier, A. Davis-Olivier, T. van Laar, R.T.M.J. Vaessen, and A. van der Eb. 1985a. Adenovirus serotype determines association and localization of the large ElB tumor antigen with cellular tumor antigen p53 in transformed cells. Mol. Cell. Biol. 5: 3084-3091.

Zantema, A., J.A.M. Fransen, A. Davis-Olivier, F.C.S. Ramaekers, G.P. Voojis, B. DeLeys, and A.J. van der Eb. 1985b. Localization of the E1B proteins of adenovirus 5 in transformed cells as revealed by interaction with monoclonal antibodies. Virology 142: 44-58.

Zauberman, A., Y. Barak, N. Ragimov, N. Levy, and M. Oren. 1993. Sequence-specific DNA binding by p53: Identification of target sites and lack of binding to p53-MDM2 complexes. EMBO J. 12: 2799-2808. 


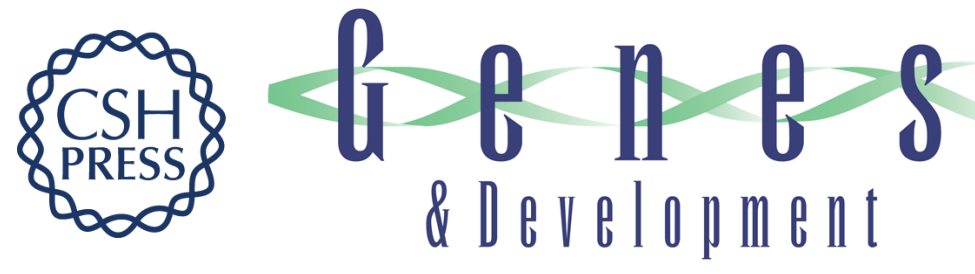

\section{Adenovirus E1B oncoprotein tethers a transcriptional repression domain to p53.}

P R Yew, X Liu and A J Berk

Genes Dev. 1994, 8:

Access the most recent version at doi:10.1101/gad.8.2.190

References This article cites 59 articles, 22 of which can be accessed free at:

http://genesdev.cshlp.org/content/8/2/190.full.html\#ref-list-1

License

Email Alerting

Service

Receive free email alerts when new articles cite this article - sign up in the box at the top right corner of the article or click here.

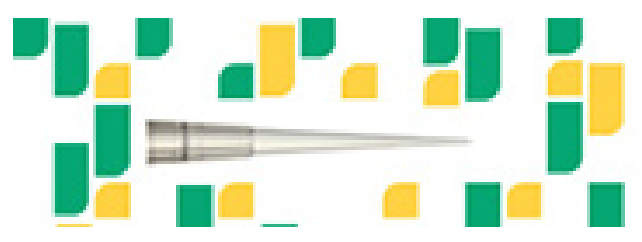

Focused on your science. 